\title{
Interest group representation in the formal design of European Union agencies
}

\author{
Ixchel Pérez Durán
}

\begin{abstract}
This article examines the decision to include interest group representation (IGR) in the most important decision-making bodies of European Union agencies (EAs). The study shows that there is considerable variation among agencies: some agencies have no representation of interest groups, others have formal rules that establish a clear distribution of the number of representatives among stakeholders, while other agencies are ambiguous with regard to the number of representatives that each group should have. In addition, interest group representatives have the right to vote in some of the agencies with IGR, while in others they have an advisory role. This article identifies three broad types of groups normally represented: representatives of capital (e.g. industry), representatives of labor (e.g. trade unions), and citizens' representatives (e.g. NGOs, consumer groups). The findings suggest that informative agencies are more likely to have IGR than agencies performing operational/management tasks. The findings also suggest that the involvement of the European Parliament in the design of EAs is more likely to make provision for the representation of stakeholders. Lastly, the case studies of the European Food Safety Agency and the European Agency for Safety and Health at Work demonstrate that interest groups could play an important role by pushing European Union institutions to include stakeholder representatives in EAs.
\end{abstract}

\section{Correspondence Address:}

Ixchel Pérez Durán, Institut Barcelona d'Estudis Internacionals (IBEI), Carrer de Ramon Trias Fargas, 25, 08005 Barcelona, Spain. email: iperez@ibei.org.

Key Words: European agencies, Delegation, Regulatory governance 


\section{Introduction}

The growth of the "regulatory state" (Majone 1994) or "regulatory capitalism" (LeviFaur \& Jordana 2005), characterized by privatization, liberalization, and deregulation, has resulted in the creation of different types of non-elected and specialized bodies which carry out executive powers (such as central banks or regulatory agencies). At the European Union level, the creation of European agencies (EAs) dates back to 1975 with the foundation of two agencies (CEDEFOP and EUROFOUND). This process of agencification was followed by two more waves of agency creation in the 1990s, and from 2000 to the present (see Busuioc, 2013). To date, there are 35 agencies covering a broad range of policy issues (e.g. food security, financial markets, medicinal products, disease control).

In the existing literature on agencification in the European Union, some studies have focused on the analysis of interactions and conflicts between political principals in the design of EAs (e.g. Curtin 2007; Dehousse 2008; Kelemen 2002; Kelemen \& Tarrant 2011). Other studies have achieved important advances in the assessment of agencies' formal-institutional independence from their political principals (Wonka \& Rittberger 2010), the de jure and de facto accountability mechanisms of agencies (e.g. Busuioc 2012, 2013; Font 2015), and the control over them exercised by both the Commission (e.g. Egeberg \& Trondal 2011) and the European Parliament (EP) (e.g. Lord 2011; Font \& Pérez Durán 2015). However, apart from a few exceptions (Borrás et al. 2007; Braun \& Arras 2014; Christensen \& Nielsen 2010; Kelemen 2002), very little scholarly atten- 
tion has addressed the role played by stakeholders in the decisions and actions performed by these agencies.

This article focuses on analyzing the design of the management structures of EAs. In particular, the article examines the decision of the agency designers to include interest group representation (IGR) in the most important decision-making bodies of EAs. In addition, this article assesses what factors explain the variation in IGR across agencies. In line with previous studies that have highlighted the reinforced role of the EP in the design and governance structures of EAs (e.g. Braun \& Arras 2014; Busuioc 2013; Font \& Pérez Durán 2015; Kelemen 2002; Lord 2011), the article examines EP involvement and two variables that previous studies on delegation and accountability (e.g. Busuioc 2013; Christensen \& Nielsen 2010; Font 2015; Wonka \& Rittberger 2010) have suggested as relevant: agency independence and agency task.

Based on an analysis of the establishing/founding documents of EAs, this study shows that there is considerable variation in the representation of stakeholders across agencies: some agencies have no representation of interest groups, others have formal rules that establish a clear distribution of the number of representatives among stakeholders, while other agencies are ambiguous with regard to the number of representatives that each group should have. In line with Schmitter and Streeck (1999 [1981]), this article identifies three broad types of groups normally represented in EAs: representatives of capital (e.g. industry), representatives of labor (e.g. trade unions), and citizens' representatives 
(e.g. NGOs, consumer groups). From the assessment of formal rules, this study also identifies that interest group representatives have the right to vote in some of the agencies with IGR; while in others they have an advisory role. Whatever the model of participation of stakeholders may be, the aim of this article is not to analyze the effectiveness or success of such groups, but rather to examine the differences in the formal rules that relate to them in different agencies and to explain the conditions that led to such variation.

The findings suggest that those agencies whose main task is the provision of information are more likely to have IGR than agencies performing operational/management tasks. The results derived from the statistical analyses and case studies of the European Food Safety Agency (EFSA) and the European Agency for Safety and Health at Work (EU-OSHA), reinforce Kelemen's work (2002), who has extensively argued that the EP demanded the establishment of formal rules enabling interest groups to engage in indirect control over agencies. Moreover, through the case studies examined, the article shows that interest groups could play an important role in pushing law-makers to involve them in the structure of the agencies. The case of EU-OSHA illustrates a tripartite corporatist bargaining model where labor and capital representatives (employers and employees) were key actors in the design of regulations regarding health, safety and working conditions, particularly during the 1960s and 1970s. In contrast, the case of EFSA illustrates the role played by industry and civil society organizations, the new key 
actors of the "regulatory state", in the design of regulations for a broad range of policy issues (e.g. food safety).

This article contributes to the literature on agencification in three ways. First, the article seeks to contribute to a general discussion on the legitimacy of the participation of interest groups in non-elected and specialized bodies at the European Union level. The focus on analyzing the formal representation of stakeholders in EAs is important because its establishment in the legal framework converts it into a right that can be claimed by interest groups and into an obligation that must be fulfilled by EU institutions. Most importantly, this analysis is relevant due to the tension found in the literature between two different positions regarding the relationship agencies may have with stakeholders. While some scholars suggest that EAs should be close to the actors involved and/or affected by policy decisions as a vehicle for generating credibility (Borrás et al 2007), other scholars suggest that these agencies were created to be independent not only from their political principals, but also from regulatees in order to avoid regulatory capture by private interests (e.g. Stigler 1971). Second, the article pays attention to two explanatory variables that have received little attention in previous studies (e.g. Braun \& Arras 2014; Christensen \& Nielsen 2010): the effect of agency independence and the role played by those agencies whose main task is the provision of information. Moreover, this article seeks to contribute to the literature by stressing the importance of analyzing the role played by interest groups in pushing EU institutions to include them in the most important decision-making bodies of EAs. 
The article is organized as follows. Section 2 discusses the process of delegation to EAs in order to draw attention to the importance of analyzing the decision of EA designers to include formal representation of interest groups. Section 3 addresses the scholarly literature on the variables that may be relevant to explain IGR in EAs and the hypotheses that may be derived from that literature. This is followed by an operationalization of the variables and analysis of the results from the statistical analysis conducted on those variables (Section 4). Finally, with the aim to understand the results in more depth, Section 5 presents the cases of EFSA and EU-OSHA.

\section{Delegation of tasks and powers to EAs: principals' decision to include IGR in}

\section{EAs}

The main theoretical model that has been used to analyze the creation of agencies is the principal-agent (P-A) approach, which "describes situations in which one party (an agent) acts on behalf of another (the principal)" (Strøm 2000, p. 266). Given that both the Commission and the Member States have delegated their functions and powers to EAs, some scholars (Curtin 2007; Dehousse 2008) have emphasized that unlike the hierarchical model of delegation presented by the P-A approach, where there is a single and unitary chain of delegation, delegation at the EU level is characterized by "multiple (legislative and/or executive) principals" (Curtin 2007, p. 526) that have been involved 
in the establishment of agencies: the Commission, the Council and the EP. In particular, some scholars (e.g. Kelemen 2002; Kelemen \& Tarrant 2011; Thatcher 2002) have demonstrated the importance of analyzing how interactions between these political principals have influenced the design of agencies. If political principals delegate their tasks and powers to agents, they also have the power "to choose the formal institutional form (notably the powers delegated and controls imposed)" (Thatcher 2002, p. 130).

In the existing research on stakeholder involvement in EAs, Kelemen (2002, p. 105) has extensively argued that the EP demanded the establishment of formal rules to control EAs, thus enabling interest groups "to engage an indirect, 'fire alarm' oversight" over agencies. In similar vein, Borrás et al (2007, p. 583) have interpreted "the institutionalization of stakeholder networks" as a means to "facilitate credible knowledge that enhances" the "input" and "output" legitimacy of EAs at the post-delegation stage. For their part, Christensen and Nielsen (2010) have moved the research forward by assessing to what extent the formal institutional design of agencies enables external stakeholders to oversee the operation of agencies through advisory boards, appeal boards and the commitology procedure. The work of Braun and Arras (2014) also represents a step forward in the literature, as it focuses on analyzing formal and actual practices of stakeholder involvement, particularly, by examining the inclusion of stakeholder groups and public consultations in EAs. 
On the basis of these studies, this article focuses on analyzing the design phase of agencies. In particular, the aim of this article is to analyze the decision of principals (understood as the main institutional designers of EAs) to include formal representation of interest groups in the most important decision-making bodies of EAs. The analysis of the institutional choices is important, since institutionalist theory reminds us that institutions matter (North 1990) insofar as they provide the rules that set out which actions are “required, prohibited, or permitted" (Ostrom 1986). In particular, institutional scholars have emphasized that rules seek to achieve "order and predictability within defined situations by: (1) creating positions (...); (2) stating how participants enter or leave positions; (3) stating which actions participants in these positions are required, permitted, or forbidden to take; and (4) stating which outcome participants are required, permitted, or forbidden to affect" (Ostrom 1986, p. 5). Therefore, although interest groups exert influence through various formal and informal channels, the analysis of formal rules is relevant since they facilitate the involvement of different stakeholders in the decisionmaking process of EAs (Mahoney 2007).

\section{Formal representation of stakeholders in EAs}

In order to analyze the decision of agency designers to include formal representation of interest groups in EAs I examine whether the establishing/founding regulations of EUagencies include mechanisms for the representation of stakeholders in their most important decision-making bodies. In particular, I focus on the management boards, the "advisory/expert forums", and the "stakeholder groups" of EAs since the primary policy 
decisions of those agencies are influenced by such bodies (Buess 2015; Busuioc 2013). The study covers the 35 EAs in existence in January 2015.

Management boards formally represent the highest level of responsibility in EAs and have specific tasks depending on the functions of the agency. Most of the boards are formally responsible for taking overall management and budget decisions, such as the appointment and/or dismissal of the agency head, the setting of an annual plan or approval of the work program, and the adoption and supervision of the budget. The composition of the management boards varies but, in general, boards can include representatives of the Member States and the Commission and, in some cases, representatives of the EP, non-EU countries, other EAs, and representatives of stakeholders (see Busuioc 2012). In addition, I also analyze the formal involvement of interest groups in the "stakeholder groups" and "advisory/expert forums". Not all EAs have provisions to include these bodies. The analysis of such permanent bodies is important because they should be consulted on actions taken by the management board and are formally responsible for providing and adopting technical and scientific advice in the policy-making process (Analytical Fiche Nr 9).

\section{What agencies have IGR and which groups are represented?}

Based on Beyers et al (2008) and Klüver (2013) this article assumes that interest groups are actors that have three main components: organizational structure, political interest 
and private status. From this definition, interest groups can include business associations, citizens groups, professional associations and trade unions, among others (Wonka et al 2010).

From the assessment of founding regulations, I identified that there is considerable variation in the level of presence of interest groups in EAs. While the statutes of 15 agencies (43 per cent of the EAs) establish the participation of stakeholders in the decisionmaking bodies of such agencies, no such provisions have been found in the statutes of 20 agencies (57 per cent of the EAs) (See Annex 1). Table 1 indicates that interest group representation was included in the management boards of nine agencies (CEDEFOP, EASA, ECHA, EFSA, EMA, EMSA, ERA, EUROFOUND and EU-OSHA). Four agencies (EBA, EIOPA, ENISA and ESMA) have a permanent "stakeholder group" that must be consulted on actions taken by the management board and which has powers to, for example, establish working groups on technical issues or submit opinions and advice (as set out in the founding documents of EBA, ESMA and EIOPA) on issues related to the tasks of the agency (e.g. regulatory technical standards and implementing technical standards). Finally, the legal provisions of two agencies (ECDC and EIGE) establish the representation of interest groups in their "advisory/expert forums", which support the management boards and constitute a mechanism for the exchange of information in the decision-making process (see Annex 2). Some EAs that do not have IGR are agencies concerned with common security and defense policies (e.g. EDA, EUISS, EUSC). 
[TABLE 1 Interest group representation in EAs]

It is worth noting that although some founding regulations were amended (such as those establishing CEDEFOP, EEA, EMCDDA, ETF, EU-OSHA, EUROFOUND and GSA), the presence/absence of stakeholders was not modified when initially stipulated (hence, this absence of changes in legislation does not allow me to increase the number of cases analyzed). For example, in most cases the composition of the management boards only altered the number of participants based on the current number of Member States, thus equalizing the number of representatives of Member States with the number of representatives of business groups and citizens/trade unions (see also Annex 2).

Moreover, I also identified three broad types of groups normally represented: industry, citizens (through, for example, NGOs and consumer groups) and employees. Particularly, in three agencies (CEDEFOP, EU-OSHA, EUROFOUND) the types of interest groups included correspond to the classic distinction identified in the seminal contribution of Schmitter and Streeck (1999 [1981]) on labor and capital representatives; that is to say, formal representation of employers and employees. 
From the assessment of founding regulations, I also identified that while some agencies have formal rules that establish a clear distribution of the number of representatives among stakeholders (in particular among those of the industry, citizen groups and/or employees' organizations), some other agencies have formal rules that are ambiguous with regard to the number of representatives that each group should have. For example, CEDEFOP has a clear number of representatives of stakeholders, since its management board makes provision for 9 representatives of professional employers as well as 9 representatives of trade union organizations. In contrast, EFSA has an ambiguous distribution since, according to the statute, "four of the members shall have their background in organizations representing consumers and other interests in the food chain" (Art. 25, founding regulation), without specifying the specific number of representatives that each group should have.

Finally, it is important to note that interest group representatives have the right to vote in seven agencies with IGR (EMA, EBA, ESMA, EIOPA, EIGE, EFSA, ENISA); while in the remaining eight agencies they have an advisory role (ECHA, EMSA, ECDC, CEDEFOP, OSHA, EUROFOUND, ERA, EASA).

\section{Explaining the variation in interest group representation across EAs}

As mentioned above, scholars have only recently started investigating IGR in EAs. Drawing on recent studies on accountability (e.g. Busuioc 2013) and delegation (e.g. 
Wonka \& Rittberger 2010), I analyze two main characteristics of agencies: their formal independence and their tasks. Since current studies have examined the role of the EP in EAs (e.g. Braun \& Arras 2014; Font \& Pérez Durán 2015; Lord 2011), I also analyze the EP involvement in EAs.

\section{Formal independence of EAs (from politicians)}

Building on previous studies on independence (e.g. Gilardi 2002; Hanretty \& Koop 2012; Verhoest et al 2004; Wonka \& Rittberger 2010), this article aims to analyze whether the designers' decision regarding the degree of formal political independence granted to each EA was accompanied by the decision to include formal representation of stakeholders in such agencies. A seminal study by Majone (1994) emphasizes that EAs were created as independent bodies "in order to enhance the credibility of their policies". On this basis, Borrás et al (2007) have interpreted the institutionalization of stakeholder participation as a vehicle for increasing such credibility. Their contribution suggests that designers of agencies sought to provide for the formal participation of stakeholders, particularly in those agencies that enjoy greater formal independence from their political principals with the aim of expanding the capacities of such agencies in the process of gathering robust information outside the conventional channels of political institutions (i.e. information produced by different types of stakeholders). In addition, on the basis of Kelemen (2002), one might expect that the more independent an agency, the more its designers would want to entrench interest group representation in order to facilitate "fire alarm" oversight. Therefore, I propose the following hypothesis: 
Hla: Agencies that enjoy greater formal independence from their political principals are more likely to include formal representation of stakeholders.

Not all scholars agree with this expectation. Bernstein $(1955$, p. 157) pointed out that agencies enjoying independence from politicians tend to be more prone to capture as agency independence "provides for maximum exposure of a regulatory commission to the most effectively organized parties in interest". In consequence, one might also expect that designers of EAs would not grant formal representation to interest groups in order to avoid regulatory capture by private interests (Shapiro \& Guston 2007), that is to say, in order to avoid that regulatees use EAs for their own ends (Stigler 1971). On this basis, I propose the following counter-hypothesis:

$H 1 b$ : Agencies that enjoy greater formal independence from their political principals are less likely to include formal representation of stakeholders.

\section{Agency task: informative agencies and regulatory agencies}

According to Busuioc (2013) and Kelemen (2002), EAs can be classified on a progressive scale (from less to more powerful competence) according to the nature of their "primary tasks". Among the different types of agencies classified by the task they per- 
form (an informative task, a management task, an operational-cooperation task, and a (quasi) regulatory task), most studies on agencification have focused their attention primarily on regulatory agencies -which are considered the most powerful agencies because their decisions are legally binding-. Nevertheless, the classical study made by Majone (1997, p. 265) highlighted the existence of two basic modes of regulation: "direct regulation", which relies, among other mechanisms, “on orders, prohibitions, legally binding standards"; and "indirect regulation" or "regulation by information", which "attempts to change behaviour indirectly", for example, by supplying policy actors “with suitable information". According to Majone (1997, p. 262), "regulation by information is often more effective than direct regulation". However, the author continues, "information can change expectations and behaviour only if it is credible". Since informative agencies play an important role through the process of collecting and transmitting information to decision-makers in the EU, one might expect that agency designers seek to provide them with formal representation of stakeholders involved in and/or affected by policies with the aim of enhancing the process of gathering and transmitting "credible" information.

$H 2 a$ : Agencies whose main function lies in information provision are more likely to provide for the representation of stakeholders. 
The article also tests the role of agencies performing regulatory tasks whose decisions are legally binding. It does so because, in a previous research Christensen and Nielsen (2010, p. 197) found that agencies within the regulatory field are less likely to have stakeholders on their boards "implying that as agencies are endowed with some authoritative power, Member Countries strengthen their ties to them by excluding other stakeholders from its governance board".

$H 2 b$ : Agencies performing regulatory tasks are less likely to include formal representation of stakeholders.

\section{The type of agency designer: the involvement of the EP}

A number of scholars (Curtin 2007; Dehousse 2008; Kelemen 2002; Kelemen \& Tarrant 2011) have extensively examined how interactions and conflicts between political principals have influenced agency design. In line with these studies, the article seeks to analyze whether the type of political principals involved in formal institutional design of EAs led to differences in the inclusion of IGR. As noted, during the first round of creation of agencies, an important role in the design of "overall governance structures" was granted to Member States (Busuioc 2013, p.22), while the EP was given a minor role in shaping agency design (Dehousse 2008). However, with the entering into force of the Maastricht Treaty, the EP has reinforced its role as a co-legislator and gained influence in the design of tasks, powers, and structures of EAs (Analytical Fiche 32). For exam- 
ple, the EP has increased its power to exercise control over agencies through the budget discharge process and some other instruments providing for the supervision of agencies (e.g. Font \& Pérez Durán 2015).

In a seminal work, McCubbins and Schwartz (1984, p. 166) argued that instead of "police-patrol" oversight, members of Congress would prefer to carry out "fire-alarm" monitoring, which consists of establishing a system of formal and informal rules and procedures "that enable individual citizens and organized interest groups to examine administrative decisions". A few years later, in a study on political control of bureaucratic decisions, McCubbins, Noll and Weingast (1987, p. 261) strengthened the idea that political actors could "stack the deck in favor of constituents who are the intended beneficiaries" of the policy by controlling the procedures of their participation (see also Guidi 2015). Drawing on these contributions on congressional oversight, Kelemen (2002, p. 111) has extensively argued that the EP "has demanded the establishment of open, transparent oversight processes, in particular those that facilitate indirect, 'firealarm' oversight by interest groups". In similar vein, recent empirical research (Braun \& Arras 2014) suggests that the involvement of the EP in the design of EAs is associated with greater stakeholder participation, particularly in public consultations. With the aim of confirming these previous findings, I also propose the following hypothesis: 
H3: Agencies that were adopted by co-decision procedure between the EP and the Council are more likely to provide for the representation of stakeholders.

\section{Operationalization and Analysis}

As noted, the study examines whether the establishing/founding regulations of EAs set out representation of stakeholders in their most important decision-making bodies (management boards, advisory/expert forums, and stakeholder groups). In particular, I use a binary dependent variable with value 1 in cases where the founding documents establish formal representation of stakeholders and value 0 otherwise (See Annex 1 and Annex 2).

To test the hypothesis on agency independence, I use the index developed by Wonka and Rittberger (2010, p. 738-739) which takes into account four general components: 1) "the formal mandate of the individual agency;" 2) "the rules for appointing the agency head;" 3) "the rules for appointing the members of an agency's management board;" and 4) the "agency's formal relationship with governments, the Commission and the EP, as well as its consultation obligations". Since the index covers 27 EAs operating in January 2009, I calculate the scores for the remaining ten agencies. To test the hypothesis on the agency's primary task, I use Busuioc's (2013) classification of EAs. In particular, I created a categorical variable with three values: $1=$ agencies whose main function lies in the collection and processing of information, $2=$ agencies performing regulatory 
tasks, $3=$ other (management/operational tasks). Finally, to test the hypothesis on EP involvement in the design of agencies, I employ a dummy variable with value 1 for agencies established under co-decision procedure between the EP and the Council and value 0 otherwise (see Annex 3).

At first glance a bivariate cross-tabulation analysis shows that $69 \%$ of agencies performing regulatory tasks, $50 \%$ of informative agencies, and $8 \%$ of agencies dealing with management or operational-cooperation tasks have formal representation of stakeholders (see Table 2). In addition, Table 3 shows that $67 \%$ of agencies adopted by co-decision have formal representation of stakeholders, while the majority of agencies that were not adopted by co-decision do not have formal representation of interest groups. When looking at the formal level of political independence, Table 4 shows that $29 \%$ of agencies with levels of independence below the mean (0.47) have IGR, while this occurs in $59 \%$ of agencies with levels of independence above the mean.

[TABLE 2 Stakeholder representation by agency task (Column Percentages)]

[TABLE 3 Stakeholder representation by co-decision procedure (Column Percentages)]

[TABLE 4 Stakeholder representation by agency independence (Column Percentages)] 
To estimate the effect of the explanatory variables on the probability of having (1) IGR in EAs, and (0) no representation, I conducted a binomial logistic regression analysis. Hosmer and Lemeshow (1989) suggest that in logistic analysis there should be a minimum of 10 cases per independent variable. Given that the sample size is small $(\mathrm{N}=35)$, each independent variable was tested in separate models. Model 1 tests the index of agency independence developed by Wonka and Rittberger (2010). Model 2 investigates the effect of the agency task. Model 3 tests the effect of EP involvement through the codecision procedure. Finally, Model 4 is the full model. Table 5 shows the results and Figures 1-2 display the predicted probabilities in order to illustrate the effect of the significant covariates on the probability of having IGR.

\section{[TABLE 5 Logistic regression model for IGR in EAs]}

Although the results should be interpreted with caution given the small-N, the results suggest the following. Firstly, although Model 1 suggests that more independent agencies are more likely to have IGR, the effect of agency independence disappeared in the full model (Model 4). This suggests that we cannot distinguish the effect of agency independence owing to multicollinearity, particularly given that independence and agency task covariates are strongly correlated (Pearson's $r=0.46, p<0.001$ ). Further analysis of qualitative data is necessary to clarify the role of formal independence. At this point, 
however, the evidence suggests that the inclusion of IGR was independent from the degree of political independence granted to each agency.

Secondly, the finding shows that, compared to agencies performing operational/management tasks, agencies performing informational tasks are more likely to have IGR (the predicted probability is 0.62 ) (see Figure 1). This finding supports the interpretation that designers of agencies sought to provide informative agencies with formal representation of stakeholders involved in and/or affected by policies with the aim of enhancing the process of gathering and transmitting "credible" information. Although Model 2 suggests that regulatory agencies are more likely to exhibit formal participation of stakeholders, the effect ceases to be significant once the remaining variables are included in the full model. However, as noted, this result should be taken cautiously given that independence and agency task — specifically, the category of regulatory agencies — are strongly correlated. In fact, subsequent ordinal logistic analysis will suggest that agencies performing regulatory tasks -as is the case of informative agencies - are also more likely to have stronger rights of participation.

[FIGURES 1-2 Marginal effects of co-decision procedure and agency task]

Thirdly, the results also suggest that the co-decision procedure has a positive and significant effect (Model 3). Specifically, the predicted probability of IGR for those agencies 
established by co-decision is .56, while for those agencies where the EP was not involved is .23 (see Figure 2). The results support Kelemen's (2002, p. 109) argument that the EP demanded the establishment of agency structures that enable "interest group allies to play a powerful role in ongoing oversight" of agencies. However, it is important to note that in the full model the effect of co-decision is not strongly significant (significant at the 0.06 percent level). This suggests the presence of some other determinant that might explain the decision to include IGR within agencies. For example, three out of the fifteen agencies that have IGR were not established by co-decision procedure (CEDEFOP, EU-OSHA and EUROFOUND). More in-depth analyses are required to explain additional determinants applying to these three agencies.

Finally, I conducted additional exploratory analysis using a different measurement of the dependent variable. As noted, interest group representatives are entitled to vote in some agencies. Therefore, I obtained an ordinal variable with three categories: 0 (if there is no IGR in the management board), 1 (if interest groups are present but not entitled to vote), and 2 (if they are present and entitled to vote). Since this measurement assumes an ordering in the scope of rights of participation granted to stakeholders within management boards, I used ordinal logistic regression (see Table 6).

[TABLE 6 Ordinal logistic regression for IGR in EAs] 
The results obtained from the ordinal logistic regression analysis are largely in line with previous results from the logistic models: firstly, agencies adopted by co-decision procedure as well as agencies performing informative tasks — in comparison with agencies performing operational/management tasks — are more likely to have IGR with stronger rights of participation. In addition, since the operationalization of the dependent variable is more precise, the analysis provides some, albeit weak, support for the hypothesis that regulatory agencies — in comparison with operational/management agencies — are also more likely to have IGR with stronger rights of participation. This result may indicate that designers of agencies are also more likely to include IGR with stronger rights of participation in agencies performing regulatory tasks - as is the case of informative agencies.

\section{The cases of the European Food Safety Agency (EFSA) and the European Agency for Safety and Health at Work (EU-OSHA)}

This article explores the cases of EFSA and EU-OSHA with the aim of understanding the results described above in greater depth. The selection of cases is based on the "diverse case" method, which "requires the selection of a set of cases - at minimum, two which are intended to represent the full range of values characterizing $\mathrm{X}, \mathrm{Y}$, or some particular X/Y relationship” (Seawright \& Gerring 2008, p. 300). In particular, these two cases are chosen on the basis of the identification of diversity in the two "causal mechanisms" suggested by quantitative analysis (agency task and co-decision procedure). EU-OSHA illustrates the case of agencies performing informative tasks and 
adopted under consultation procedure; while EFSA illustrates the case of agencies performing regulatory tasks and established by a co-decision agreement with the EP.

In addition, the article explores these two cases with the aim, on the one hand, of understanding better the role played by the EP in agency design - beyond the introduction of the co-decision procedure -, while on the other hand, of examining the involvement of a variable not included in the statistical analysis: the role played by the stakeholders in such institutional design.

The case of EU-OSHA illustrates a tripartite corporatist bargaining model (Schmitter and Streeck (1999 [1981])) where labor and capital representatives (employers and employees) were key actors in the design of regulations regarding health, safety and working conditions, particularly during the 1960s and 1970s. In contrast, the case of EFSA illustrates the role played by industry and civil society organizations, the new "key actors" of the "regulatory state", in the design of regulations for a broad range of policy issues (e.g. environmental, food safety, medicinal products, electricity, and railways). These examples also illustrate how political actors could "stack the deck" (McCubbins, Noll \& Weingast 1987) in favor of certain constituents by controlling the procedures of their participation (see also Guidi, 2015). Hence, while the first case illustrates how the EP proposed a set of amendments with the aim of benefitting the "corporatist" system of interest group representation, the second case shows how the EP pushed for the socalled "pluralist" system of interest group representation (Streeck 1991). 


\section{The case of $\mathrm{EU}-\mathrm{OSHA}$}

The creation of EU-OSHA was preceded by an increase in national legislation on safety at work, such as the Occupational Safety and Health Act of 1970 in the United States, the Health and Safety at Work Act of 1974 in the UK, or the Work Environment Act of 1977 in Sweden. The creation of such policy decisions on health and safety at work derived from a series of workplace safety incidents and workers' mobilization. For example, Korostoff et al. (1991, p. 50-51) describe how in the case of Sweden a massive strike of miners at the LKAB mine in Kiruna in 1969 led to the adoption by the ruling Social Democratic Party of "occupational health and safety as one of its main platform issues", and to the adoption by the Swedish Parliament of "several important changes to encourage worker participation", thereby giving rise to the creation of the Work Environment Fund in 1972, and the Work Environment Act in 1977. In addition, Korostoff et al (1991) mention that national governments responded with the establishment of tripartite cooperation between national governments, trade unions and employers' organizations. For example, in the case of Great Britain, the Labour government adopted the Health and Safety at Work Act in 1974, which resulted in the creation of the Health and Safety Commission including participation from representatives of "the Confederation of British Industries (as the employer representative)", as well as representatives of "the Trade Union Congress (as the employee representatives)" (Korostoff et al 1991, p. $82-83)$. 
At the European level, Streeck (1991) points out that after 1968 the accession to power by social-democratic parties in major Member Countries facilitated an ambitious program of social policies adopting a tripartite cooperation model. For example, the First Summit Conference of the heads of state and government held in Paris in 1972 demanded "a coordinated policy" aimed at "improving working conditions and conditions of life, at closely involving workers in the progress of firms". Later, the Social Action Program of the European Communities - drew up by the Commission and adopted by Council resolution in January 1974 - also emphasized the need for "the involvement of management and labour in the economic and social decisions of the Community".

The creation of EU-OSHA was also preceded by the creation of the "Advisory Committee on Safety, Hygiene and Protection at Work" in June 1974, a commitology committee established "with the aim to assist the Commission and to facilitate cooperation between national governments, trade unions and employers' organizations" (Art. 2). This Committee was created as a tripartite body by including representatives of the governments, the trade unions and the employers' organizations (see Art. 4). In similar vein, one year later - in May 1975 - the Council established a new European Agency, the European Foundation for the Improvement of Living and Working Conditions (EUROFOUND) which also established a tripartite administrative board. 
Some other actions were subsequently adopted. For example, the First Action Program of the European Communities on Safety and Health at Work was established in 1978; and the Single European Act was adopted in 1986. A crucial step was the establishment of the Community Charter of Fundamental Social Rights for Workers, approved by the heads of the European Community Member States (with the exception of the United Kingdom) in December 1989, from which the Commission prepared an action program concerning the implementation of this Charter and proposing the creation of a special European agency.

Therefore, in 1991 the Commission laid out a proposal for establishing EU-OSHA, setting out as its main task to promote information exchange among the Commission and the Member States. According to this proposal, the agency would have an administrative board consisting of three representatives of the Commission (appointed by the Commission), a representative of each Member State, and "12 representatives of the two sides of industry in the Member States, comprising six representatives of workers' trade union organizations and six representatives of employers' professional organizations" (all of them appointed by the Commission after consultations with the Member States). According to the proposal, stakeholder representatives should be chosen from the members of the Advisory Committee on Safety, Hygiene and Health Protection at Work, which, as noted, was composed of representatives of Member States, national trade unions and national employers. 
In April 1992, the Economic and Social Committee (ESC) responded, highlighting the "restricted representation of workers and employers" in the composition of the administrative board as well as their restricted participation in the appointment procedure of such representatives:

The Committee has reservations about the workers' and employers' representatives for the Agency being selected by the Commission after consultation with the Member States. The Committee would propose instead that the workers' and employers' representatives should be appointed by the Commission in consultation with the Member States after nomination by the most representative European federations of trade unions and employer associations.

As noted, EU-OSHA was not established by co-decision procedure. However, it is important to note that even before the co-decision was introduced, the EP had the power to propose amendments. As Lord (2011, p. 914) notes “[c]o-decision obviously gives the Parliament veto powers and the power to propose amendments that can be backed by the threat of veto. Yet, even under Consultation, it often does succeed in amending legislation." Hence, although EU-OSHA was established by consultation, the EP played an important role by proposing a set of amendments, some of which aimed at strengthening the participation of stakeholders. For example, in April 1994, the EP proposed including: "Twenty-four representatives of employers' and labour organizations, of whom 12 shall represent labour and 12 the employers" (Amendment, No C 128/508). Moreover, regarding the appointment of these representatives, the text amended by the EP set out the following:

The members (..) shall be appointed by the Commission from the members of the Advisory Committee on Safety, Hygiene and Health Protection at Work, upon 
nomination by the most representative European employers' and workers' federations and after consultation of the Member States.

After a process of consultation with the ESC and the EP, on 18th July 1994, the Council adopted the founding document of EU-OSHA, which established a management board composed of the number of stakeholder representatives in line with the proposal presented by the Commission in 1991. Although the number of stakeholder representatives did not correspond to the amendment proposed by the EP, the regulation gave stakeholders an important role in the appointment process, since representatives of employers and employees should be appointed by the Council (and not by the Commission) from the members of the Advisory Committee on Safety, Hygiene and Health Protection at Work "on a proposal from the groups of those members on the Committee, on the basis of one member for each Member State" (see Art. 8).

Five months later, in December 1994, the Commission laid out a new proposal for amendments with regard to the number of representatives of the administrative board, whose amended composition responded to the accession of new Member States (Austria, Finland and Sweden) and the previous amendments proposed by the EP: 15 members representing the governments of the Member States; 15 members representing the employers' organizations; 15 members representing the employees' organizations, and three members representing the Commission. This amendment was approved in June 1995. Therefore, once EU-OSHA started to be fully operational in 1996, it began operating with a tripartite management board composed of the same number of members 
representing the Member States, the employers and the employees. The last set of amendments of the founding document of 2005 did not modify the composition of the management board, but proposed a new formulation that allowed for the modification of such composition, as the number of Member States varies.

\section{The case of EFSA}

Several scholars have emphasized that a series of food incidents/crises in the late 1990s, particularly the outbreak of "mad cow" disease (Bovine Spongiform Encephalopathy, or BSE) in the UK, drew attention to the need to formulate more integrated food safety regulation within the EU (e.g. Paul 2012; Ugland \& Veggeland 2006; Vos 2000). The response of the Commission was the creation of the Office of Veterinary and Phytosanitary Inspection and Control (OVPIC) in December 1991. The EP, meanwhile, responded by creating a temporary committee of inquiry on BSE in July 1996, the discussions of which were summarized in the "Medina Report" of February 1997. In the "Medina Report" the EP expressed concerns regarding the lack of transparency with respect to the decisions and actions of the Commission on BSE (Vos 2000) and called for the creation of "a body similar to the Food and Drug Administration in the US or the health administrations in some Member States" (EP Report on BSE, p. 13). Moreover, the report highlighted that "the existing Community rules on food law" were "complex and opaque" and called on the Commission to "draw up a framework directive on Community food law, following wide-ranging consultations involving the different stages of the food chain and consumers' organizations" (EP Report on BSE, p. 34). 
The Commission was not averse to the idea of including different actors of the food chain (Paul 2012). For example, in 1997, the Commission prepared the Green Paper on the Principles of Food Law, and stated among its goals "to place the primary responsibility for food safety on industry, producers and suppliers" (Green Paper on European Food Law, pp. 1-2). However, as Kelemen (2002) has pointed out, initially the Commission decided not to transform OVPIC into an independent agency in order to maintain the field of food and veterinary inspection under direct control and also to avoid the creation of an agency controlled by Member States - a decision which, according to Kelemen, was also supported by some MEPs.

After a further crisis episode emerged with the Dioxin Affair in Belgium in May 1999, the demand to improve food safety policy in the EU intensified. Hence, the Commission asked three scientists (Philip James, Fritz Kemper and Gerard Pascal) to evaluate the possibility of creating an agency. Along the lines of the US Food and Drug Administration (FDA), the report of the experts proposed the creation of the European Food and Public Health Authority. With regard to the scope of its interaction with stakeholders, the report reads: [the] "administrative board may be composed of some representatives of the stakeholders but it is not the current practice in setting up the agencies" (KemperPascal-James Report, p. 23). Specifically, they proposed an administrative structure analogous to the "OLAF system", with a Board composed of nine members:

[T]hree figures of major international repute appointed by the Presidents of the Commission, of the EP and the Council of Ministers. A further four members should be appointed from individuals proposed by the principal stakeholders, i.e. 
two from the consumer, environmental and public interest groups and two from the industrial sector. It is important, however, that these individuals, approved by the Parliament, the Commission and the Council of Ministers conduct themselves as general board members and not selectively as formal representatives of constituent stakeholders (...). Finally, two further members should be appointed by the Scientific Community through the network of the principal scientific organizations within Member States (Kemper-Pascal-James Report, p. 45).

The Kemper-Pascal-James Report shows that interest groups were also involved in the development of the proposal. In particular, the report lists the associations and individuals attending 'a special open day hearing on the future of scientific advice' in November 1999: more than fifty associations attended those hearings (for example, Alpharma, BASF, BEUC, the British Retail Consortium, CEFIC, CELCAA/COCERAL, CIAA, CIFOF, COPA-COGECA, ECPA, the German Farmers' Union) and ten associations provided written contributions after attending such hearings. Stakeholders were also close to the Commission. In January 2000, the Commission published its White Paper on Food Safety, emphasizing the need to clarify "the roles of all stakeholders in the food chain (farmers and food manufacturers/operators; the competent authorities in Member States and third countries; the Commission; consumers)" (White Paper on Food Safety, p. 8). In particular, the Commission proposed the creation of an 'Advisory Committee on Food Safety", which had as its objective "to improve involvement of all stakeholders in the Community food safety policy by streamlining the existing Advisory Committees" (White Paper on Food Safety, p. 52). The Commission also invited interested parties to make comments on the White Paper: twenty-six organizations provided comments (e.g. CEFIC, CELCAA, CIAA, FDF). Again, stakeholders emphasized the im- 
portance of being involved in the decisions of the agency. As an illustration of this statement:

[C]lear structures have to be established which enable the stakeholders to provide their input without compromising the independence of the agency (Comment to the White Paper on Food Safety, CIAA).

The Commission then laid out the proposal for establishing the European Food Authority in November 2000. The proposal suggested that the "Management Board shall be composed of four representatives appointed by the European Parliament, four representatives appointed by the Council, four representatives appointed by the Commission and four representatives of consumers and industry designated by the Commission" (Art. 24).

In May 2001, the Economic and Social Committee responded, emphasizing the need to clarify the composition of the management board: "[c]larification is needed on the likely composition and procedures/criteria to be used for the selection of candidates. (...) the ESC would stress the need for primary, secondary and tertiary operators of the food sector to be on the board so as to underline the integrated approach to the food chain". In similar vein, in August 2001 the EP proposed some amendments with the aim of including mechanisms to exercise control over the agency. The EP did not propose to modify the composition of the management board put forward by the Commission. However, the EP had a strong influence on the criteria for the selection of management board members (Kelemen 2002). Following the negotiations, the criteria read: "the members 
should be appointed by the Council in consultation with the EP from a list drawn up by the Commission" (Art. 25).

Hence, in January 2002, the EP and the Council agreed on a new regulation establishing EFSA (Kelemen 2002). The study of EFSA confirms that the EP played an important role in facilitating interest group access to the most important decision-making bodies of EAs, with the aim of engaging "fire alarm" oversight mechanisms through these "interest group allies". However, the regular involvement of stakeholders in the process of creation of EFSA is highly indicative that they may also have affected the decision to include IGR in the EAs.

\section{Conclusions}

As a consequence of the rise of the "regulatory state", governments have delegated powers to specialized and not elected bodies "in order to enhance the credibility of their policies" (Majone 1994). Perhaps it has been the very debate about their (lack of) legitimacy that has led some agencies to include interest groups in their decision-making process, since in many cases interest groups can been seen "as vehicles of popular representation" (Baumgartner \& Leech 1998, p. 83). However, EAs were created to tackle the credible commitment problem and, particularly, to be independent from politicians and regulatees. 
This article has shown that formal rules facilitate the involvement of interest groups in EAs, since they set out which actors are permitted to participate in the policy-decision process. In particular, in line with Schmitter and Streeck (1999 [1981]), this article identified that the institutional design of agencies ensures the representation of three types of groups: those that represent the owners of capital (e.g. industry), those that represent the employees (e.g. trade unions), and those representing citizens (e.g. NGOs, consumer groups). However, while some agencies have formal provisions that set out a clear representation between these types of groups, other agencies have ambiguous rules with regard to the number of representatives that each group should have. Moreover, this study also identified that interest group representatives have the right to vote in some of the agencies with IGR, while in others they have an advisory role.

The study also examined the effect of agency independence, agency task, and EP involvement on IGR in EAs. Being cautious in the interpretation of the results of this study given the small number of cases, the results suggested that, compared to agencies performing operational/management tasks, agencies whose main function is the provision of policy information to the Commission and the Member States are more likely to have interest group representation. The analysis also provides some, albeit weak, support for the hypothesis that regulatory agencies — in comparison with operational/management agencies - are also more likely to have IGR with stronger rights of participation. In addition, the results derived from the statistical analyses and case studies of EFSA and EU-OSHA suggested that the EP demanded the establishment of formal rules enabling 
interest groups to engage in indirect control over agencies. Moreover, the case studies examined support the idea that, beyond formal institutions, interest groups could play an important role by pushing EU institutions to include stakeholder representatives in EAs. The case of EU-OSHA illustrates that the EP proposed a set of amendments with the aim of benefitting a "corporatist" system of interest group representation where labor and capital representatives were key actors in the design of regulations, whereas the case of EFSA shows that the EP pushed for the so-called "pluralist" system of interest group representation where industry and civil society organizations are the new key actors of the "regulatory state".

This article is one step towards a broader area of research on interest groups in EAs. The next step will be to focus on analyzing how proportional the stakeholder representation is. This is important because at this point the discussion over the inclusion of interest groups in EU agencies has been disconnected from the discussion over the degree to which each group should be represented. I leave the analysis of equal proportionality in their representation to future research.

\section{References}

Baumgartner FR, Leech BL (1998) The Importance of Groups in Politics and in Political Science. Princeton: Princeton University Press.

Bernstein M (1955) Regulating Business By Independent Commission, Princeton University Press, Princeton.

Beyers J, Eising R, Maloney W (2008) Researching Interest Group Politics in Europe and Elsewhere: Much We Study, Little We Know? West European Politics 31(6), 1103-1128. 
Borrás S, Koutalakis C, Wendler F (2007) 'European agencies and input legitimacy: EFSA, EMeA and EPO in the post-delegation phase. Journal of European Integration 29(5), 583-600.

Braun C, Arras S (2014) EU agencies as an additional venue for interest group mobilization. Paper presented in the 5th Biennial Conference on Regulatory Governance, Barcelona, Spain, 25-27 June 2014.

Buess M (2015) European Union agencies and their management boards: an assessment of accountability and demoi-cratic legitimacy. Journal of European Public Policy 22(1), 94-111

Busuioc M (2013) European Agencies: Law and Practices of Accountability, Oxford: Oxford University Press.

(2012) 'European agencies and their boards: promises and pitfalls of accountability beyond design. Journal of European Public Policies 19(5), 719-36.

Christensen JG, Nielsen VL (2010) Administrative capacity, structural choice and the creation of EU agencies, Journal of European Public Policy (17)2, 176-204.

Curtin D (2007) Holding (Quasi-)Autonomous EU Administrative Actors to Public Account. European Law Journal 13(4), 523-541.

Dehousse R (2008) Delegation of powers in the European union: The need for a multiprincipals model. West European Politics 31(4), 789-805.

Egeberg M, Trondal J (2011) EU-level agencies: new executive centre formation or vehicles for national control? Journal of European Public Policy 18(6), 868-87.

Font N (2015) Designing Accountability Regimes at the European Union Level, in A. Bianculli, J. Jordana and X. Fernández-Marín (eds), Accountability and Regulatory Governance. Audiences, Controls and Responsibilities in the Politics of Regulation, London: Palgrave.

Font N, Pérez Durán I (2015) The European Parliament oversight of EU agencies through written questions. Journal of European Public Policy (OnlineFirst)

Gilardi F (2002) Policy credibility and delegation to independent regulatory agencies: a comparative empirical analysis. Journal of European Public Policy 9(6), 873-93.

Guidi M (2015) Modelling the Relationship Between Independence and Accountability of Regulatory Agencies, in A. Bianculli, J. Jordana and X. Fernández-Marín (eds), Accountability and Regulatory Governance. Audiences, Controls and Responsibilities in the Politics of Regulation, London: Palgrave.

Hanretty C, Koop C (2012) Measuring the formal independence of regulatory agencies. Journal of European Public Policy 19(2), 198-216.

Hosmer DW, Lemeshow S (1989) Applied logistic regression. New York: Wiley.

Kelemen DR (2002) The Politics of 'Eurocratic' Structure and the New European Agencies. West European Politics 25(4), 93-118. 
Kelemen DR, Tarrant AD (2011) The Political Foundations of the Eurocracy. West European Politics 34(5), 922-947.

Klüver H (2013) Lobbying as a Collective Enterprise: Winners and Losers of Policy Formulation in the European Union. Journal of European Public Policy 20(1), 59-76.

Korostoff JE, Zimmermann LM, Ryan CE (1991) Rethinking the OSHA approach to workplace safety: a look at worker participation in the enforcement of safety regulations in Sweden, France and Great Britain. Comparative Labor Law Journal 13, 45-95.

Levi-Faur D, Jordana J. (2005) The global diffusion of regulatory capitalism. Annals of the American Academy of Political and Social Science 598, 12-32.

Lord C (2011) The European Parliament and the legitimation of agencification. Journal of European Public Policy 18(6), 909-25.

Mahoney C (2007) Lobbying success in the United States and the European Union. Journal of Public Policy 27(1), 35-56.

Majone G (1994) The rise of the regulatory state in Europe. West European Politics 17(3), 77-101.

Majone G (1997) The new European agencies: regulation by information. Journal of European Public Policy 42(2), 262-275.

McCubbins MD, Schwartz T (1984) Congressional oversight overlooked: police patrols versus fire alarms. American Journal of Political Science 28(1), 165 - 79.

McCubbins MD, Noll RG \& Weingast BR (1987) Administrative Procedures as Instruments of Political Control. Journal of Law, Economics, \& Organization 3(2), 243277.

North D (1990) Institutions, institutional change and economic performance. Cambridge, UK: Cambridge University Press.

Ostrom E (1986) An agenda for the study of institutions. Public Choice 48: 3-25.

Paul KT (2012) The europeanization of food safety: a discourse-analytical approach. Journal of European Public Policy 19(4), 549-566.

Seawright, J., \& Gerring, J. (2008). Case selection techniques in case study research: A menu of qualitative and quantitative options. Political Research Quarterly 61(2), 294-308.

Schmitter PC, Streeck W (1999 [1981]) The Organization of Business Interests: Studying the Associative Action of Business in Advanced Industrial Societies. Max Planck Institute for the Study of Societies. Discussion Paper 99/1.

Shapiro S, Guston D (2007) Procedural control of the bureaucracy, peer review, and episternic drift. Journal of Public Administration Research and Theory 17(4), 535551. 
Stigler GJ (1971) The theory of economic regulation. The Bell Journal of Economics and Management Science 2(1), 3-21.

Streeck W (1991) From National Corporatism to Transnational Pluralism: European Interest Politics and the Single Market. The Helen Kellogg Institute for International Studies, University of Notre Dame, Indiana. Working Paper No.164.

Strøm K (2000) Delegation and accountability in parliamentary democracies. European Journal of Political Research 37(3), 261-289.

Thatcher M (2002) Delegation to independent regulatory agencies: pressures, functions and contextual mediation. West European Politics 25(1), 125-47.

Ugland T, Veggeland F (2006) Experiments in food safety policy integration in the European Union. Journal of Common Market Studies 44(3), 607-24.

Verhoest K, Peters BG, Bouckaert G, Verschuere B (2004) The study of organisational autonomy: A conceptual review. Public Administration and Development 24(2), 101-118.

Vos E (2000) EU food safety regulation in the aftermath of the BSE crisis. Journal of Consumer Policy 23(3), 227-55.

Wonka A, Rittberger B (2010) Credibility, Complexity and Uncertainty: Explaining the Institutional Independence of 29 EU Agencies. West European Politics 33(4), 730752. 